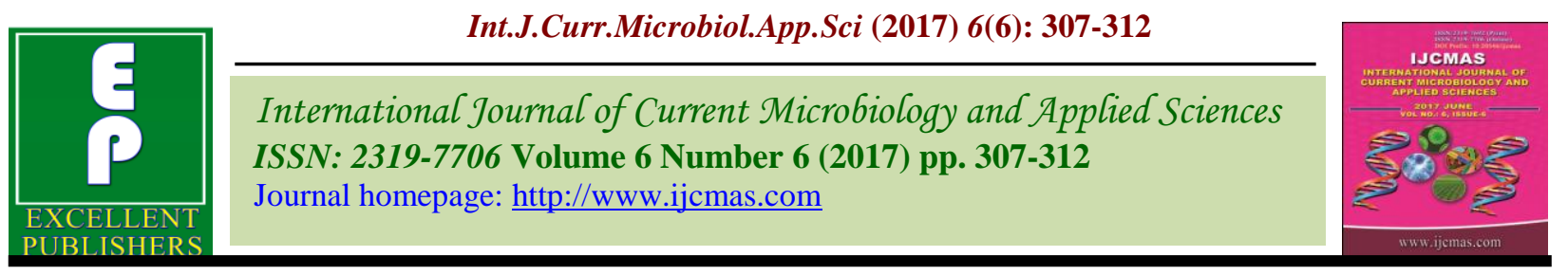

Original Research Article https://doi.org/10.20546/ijcmas.2017.606.037

\title{
Estimation of Physical Properties of soil of Sri Ganganagar District-Rajasthan, India
}

\author{
Manpreet Kaur*, Narendra Swaroop, Tarence Thomas and Arun A. David \\ Department of Soil Science and Agricultural Chemistry Sam Higginbottom University of \\ Agriculture, Technology and Sciences, Allahabad- 211007, U.P., India \\ *Corresponding author
}

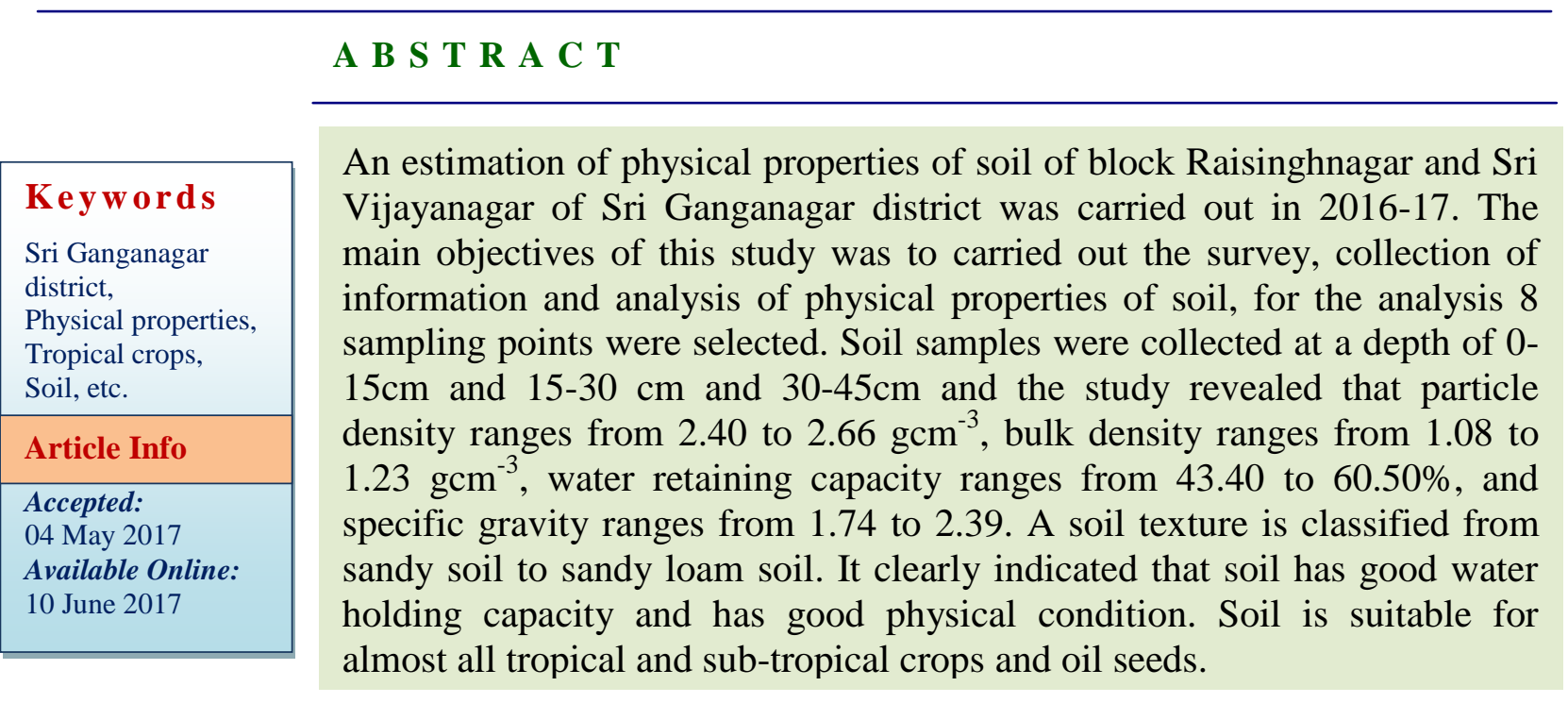

\section{Introduction}

"Nutrients" may be defined as the chemical compounds required by an organism. The plant nutrients may be divided into macronutrients (primary and secondary nutrients) and micro-nutrients. Macro-nutrients are found and needed in plants in relatively higher amounts than micro-nutrients (Das, 2004).

Changes in land use and soil management can have a marked effect on the soil organic matter (OM) content. Several studies in the past have shown that deforestation and cultivation of virgin soils often lead to depletion of macro-nutrients (N, P, S) present as part of complex organic polymers.
Changes in the land use scenario and greediness of getting high return through intensive cultivation by the resource-rich farmers have resulted in changes in soil quality and leading to declined soil fertility (Singh and Singh, 2005).

Soil hydro-physical properties of soil may help in formulating improved water management strategies for improving the prospects of yield enhancement and stabilization of orchards in the region. Formulation of sound management strategy to improve water use efficiency will require a clear understanding of soil water functional 
relationship, i.e. the capacity, intensity and rate variables (rate of water movement through soil) of moisture availability in the soils and relationship among them.

In Sri Ganganagar district rainfall less than $400 \mathrm{~mm}$, texture sandy to sandy loam, it contains a high percentage of soluble salt and has high $\mathrm{pH}$ value. It has varying percentage of calcium carbonate and generally poor in organic matter these soil are pale brown, single grained, deep and well drained. One million hectare area is under problematic soils (saline and alkaline). Due to scarcity of rainfall there is limited availability of ground water. The crops suffer due to high temperature and wind velocity. The soils are well supplied with potassium. Micro elemental deficiencies particularly zinc and sulphur has also been observed in pockets. Present investigation was useful in judging the deficiency of various element and thereby use of fertilizers depending on their status.

Hence, a detailed study for characterization and evaluation of soils is needed to realize the concept of soil health and quality analysis successfully. With this objective, a study has been undertaken in soil resources inventory for land use planning in Sri Ganganagar district of Rajasthan.

\section{Materials and Methods}

Sri Ganganagar is a Northern most district of Rajasthan state in Western India. The town of Sri Ganganagar is the district headquarters. Sri Ganganagar district is located between 28.8 to $30.6^{\circ} \mathrm{N}$ latitude and 72.2 to $75.3^{\circ} \mathrm{E}$ longitudes. Sri Ganganagar is situated at the point where the Sutlej waters enter Rajasthan. The region irrigated by the Gang canal and the Bhakhra canal tributaries.

Surface soil of the farmer's field from different village of Raisinghnagar block and
Sri Vijaynagar of Sri Ganganagar district, were sampled randomly to a depth of 0-15 $\mathrm{cm}, 15-30 \mathrm{~cm} 30-45 \mathrm{~cm}$ totally, 24 soil samples were collected from two tehsil of Sri Ganganagar, 4 villages were selected from each block and eight villages are selected they are 7KSD (V1), 6TK (V2), Slampura (V3), 6PTD (V4), 40GB (V5), 28GB (V6), 22GB (V7) and 46GB (V8). The soil sample was mixed thoroughly and about a half kilogram of composite samples from farmer's field of different villages was taken for analysis.

\section{Results and Discussion}

Of the following soils, particle density, bulk density, specific gravity, water retaining capacity of given in figure 1 to 4 and in table 1 the statistical data of soil texture was given. The highest value of particle density is found in 46GB (V8) village at depth $15-30 \mathrm{~cm}(2.65$ $\mathrm{gcm}^{-3}$ ) and lowest value at depth $30-45 \mathrm{~cm}$ $\left(2.40 \mathrm{gcm}^{-3}\right)$ of $22 \mathrm{~GB}$ (V7) village. Soil Similar results were reported by Oyedele (2009). Bulk density in villages and depths was found to be significant at both levels. The highest value of is found at 22GB (V6) at depth $30-45 \mathrm{~cm}\left(1.23 \mathrm{gcm}^{-3}\right)$ and lowest value at depth $0-15 \mathrm{~cm}\left(1.08 \mathrm{gcm}^{-3}\right)$ of $46 \mathrm{~GB}$ (V8), village. Similar results were reported by Chaudhari (2013).

Water retaining capacity was found highest at Slampura (V3) village at depth $0-15 \mathrm{~cm}$ $(60.50 \%)$ and lowest at 28GB (V6) village at depth of $30-45 \mathrm{~cm}(43.40 \%)$. Similar results were reported by Sujatha et al., (2016). Saturation of soil that is specific gravity was found highest at 6TK (V2) at depth $30-45 \mathrm{~cm}$ (2.39) and lowest value founded at depth of 0$15 \mathrm{~cm}$ (1.74) of 6PTD (V4) village soil. Soil textural classes (Table 1) were sandy soil and sandy loam soil which is varies depends on places. Analysis data graphs and tables are below. 
Fig.1 Particle density values of soils of Sri Ganganagar district, Rajasthan

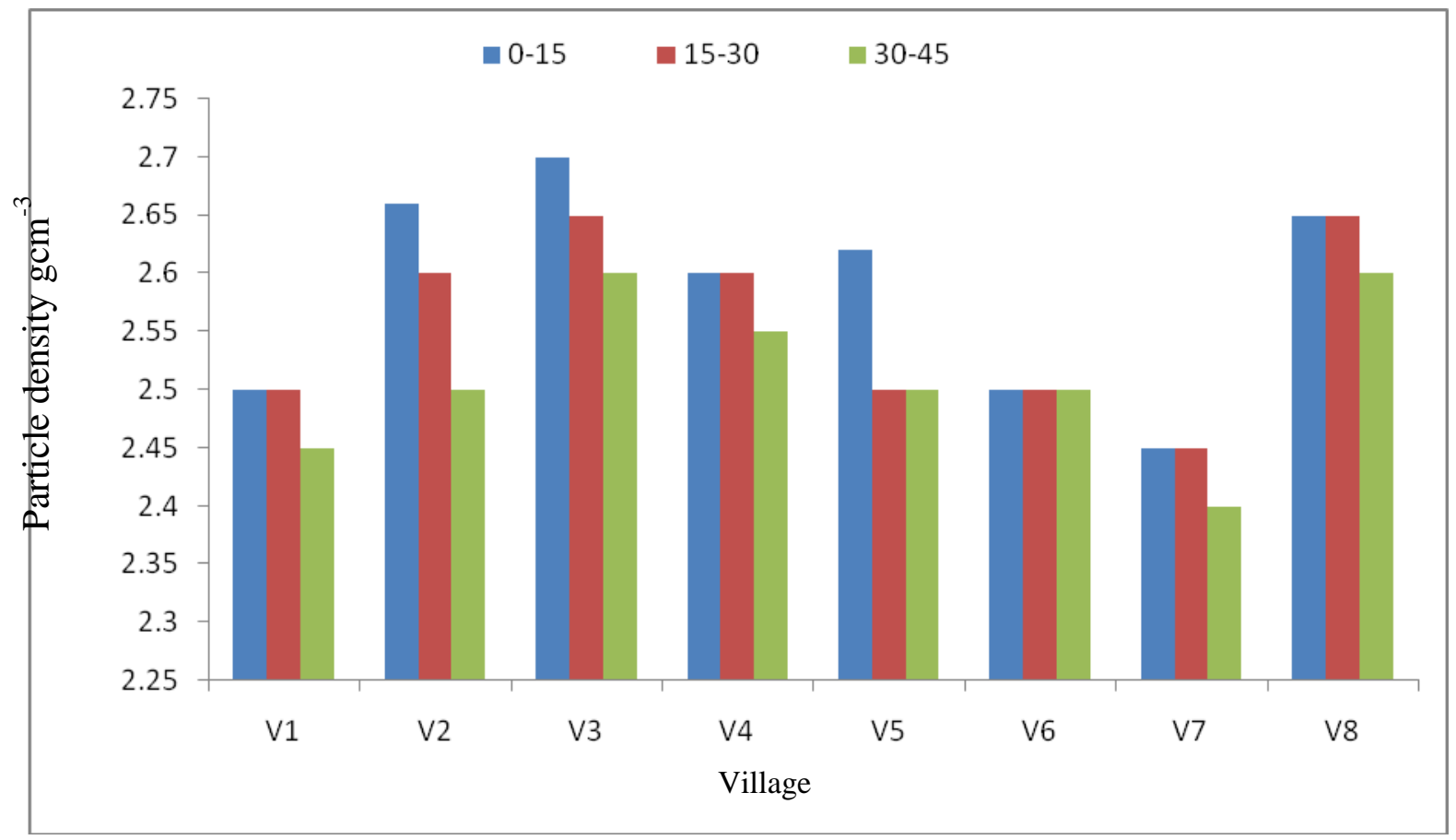

Fig.2 Bulk density values of soils of Sri Ganganagar district, Rajasthan

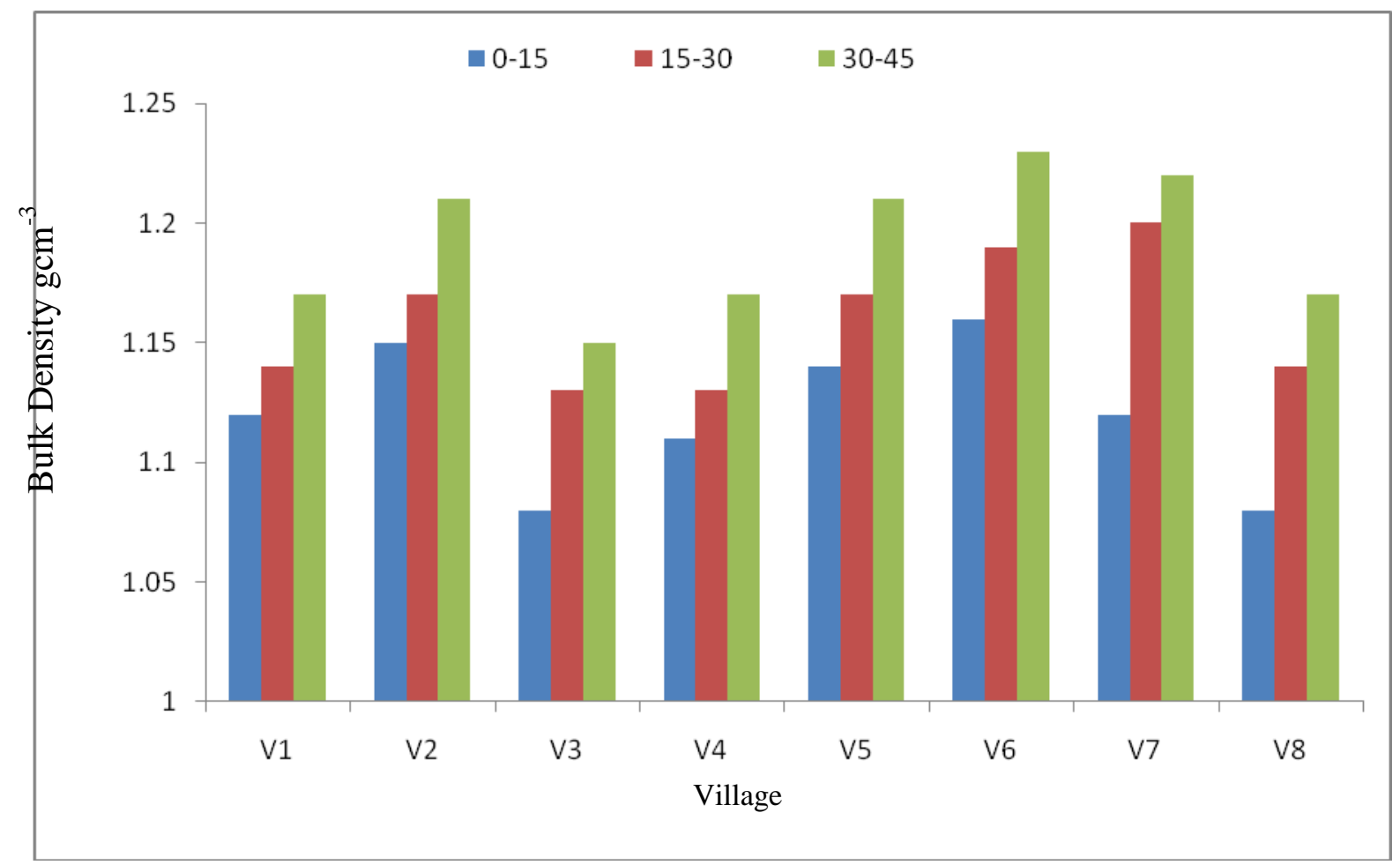


Fig.3 Water holding capacity values of soils of Sri Ganganagar district, Rajasthan

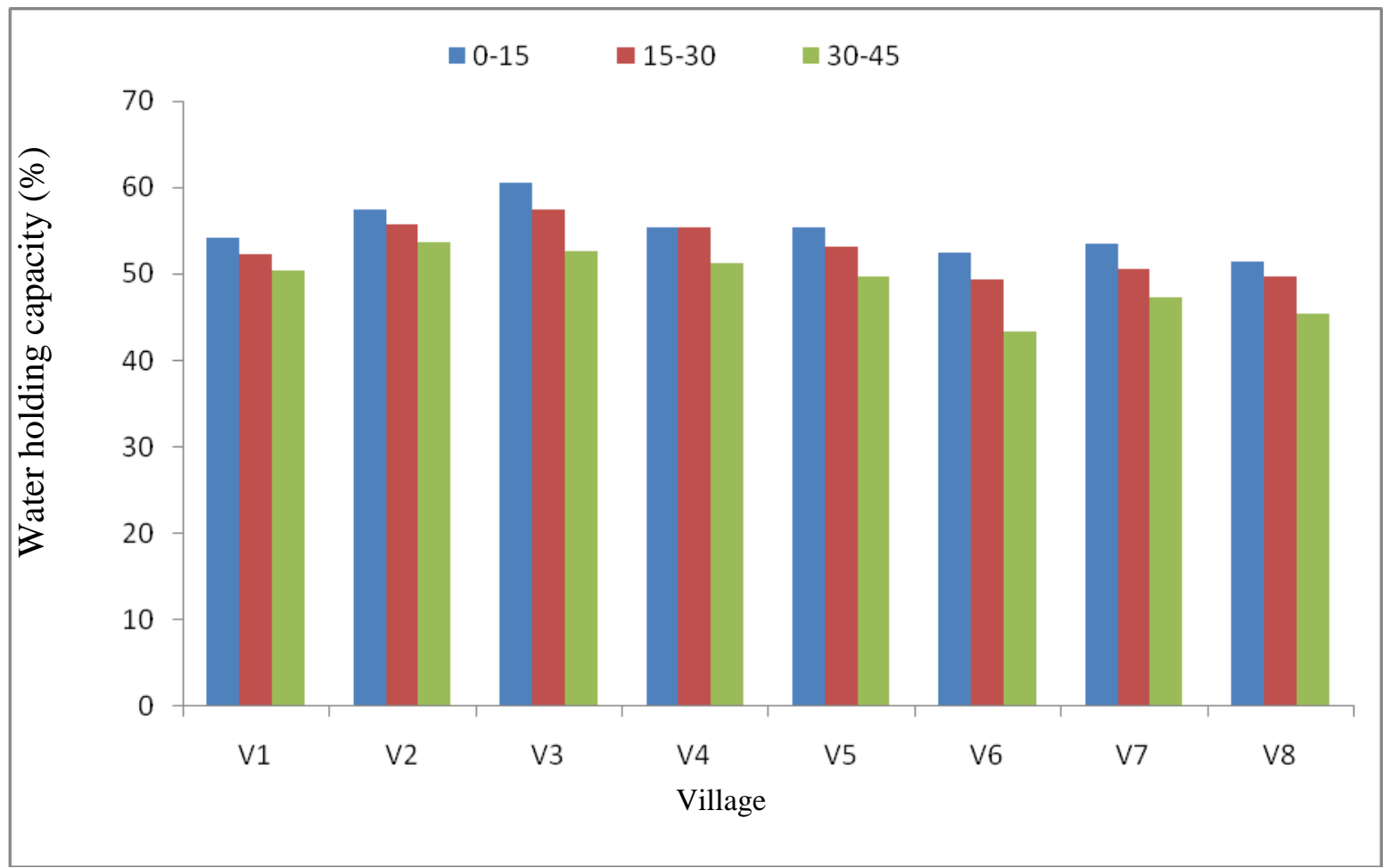

Fig.4 Specific gravity values of soils of Sri Ganganagar district, Rajasthan

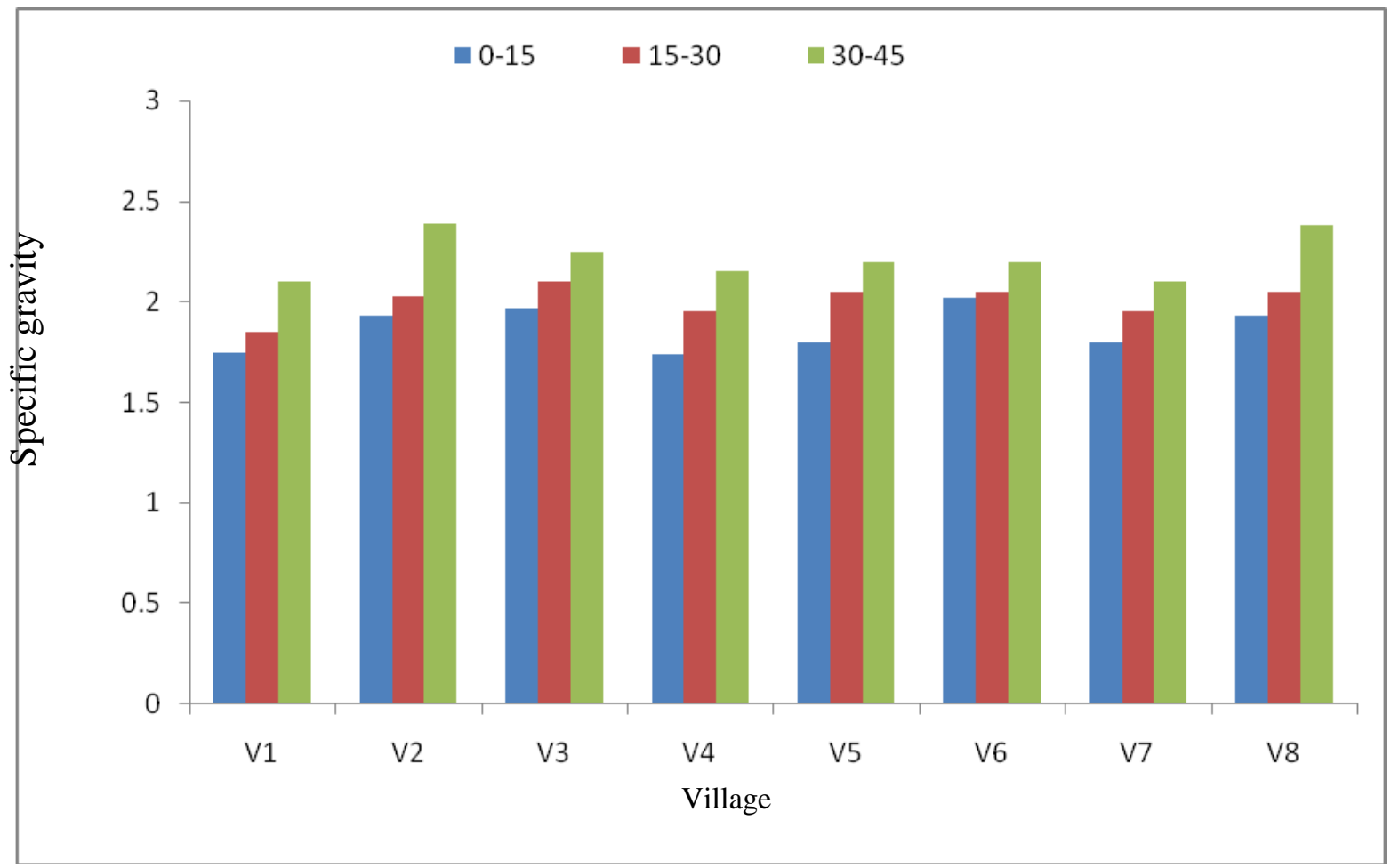


Table.1 Soil textural classes of soils of Sri Ganganagar district, Rajasthan

\begin{tabular}{ccccc}
\hline Villages & \% Sand & \% Silt & \% Clay & Textural Class \\
\hline 7KSD $\left(\mathbf{V}_{\mathbf{1}}\right)$ & 69.8 & 15.5 & 14.7 & Sandy loam \\
$\mathbf{6 T K}\left(\mathbf{V}_{\mathbf{2}}\right)$ & 73.3 & 18.5 & 8.20 & Sandy loam \\
Slampura $\left(\mathbf{V}_{\mathbf{3}}\right)$ & 84.8 & 7.3 & 7.9 & Sandy \\
$\mathbf{6 P T D}\left(\mathbf{V}_{\mathbf{4}}\right)$ & 87.3 & 5.9 & 6.8 & Sandy \\
$\mathbf{4 0 G B}\left(\mathbf{V}_{\mathbf{5}}\right)$ & 60.3 & 24.5 & 15.2 & Sandy loam \\
$\mathbf{2 8 G B}\left(\mathbf{V}_{\mathbf{6}}\right)$ & 75.7 & 10.0 & 11.0 & Sandy loam \\
$\mathbf{2 2 G B}\left(\mathbf{V}_{\mathbf{7}}\right)$ & 74.5 & 9.5 & 12.5 & Sandy loam \\
$\mathbf{4 6 G B}\left(\mathbf{V}_{\mathbf{8}}\right)$ & 67.3 & 19.6 & 13.1 & Sandy loam \\
\hline
\end{tabular}

In conclusion, the present study of physical analysis of soil samples of Sri Ganganagar district has showed difference in the physical characteristics. Particle density of the soil was higher in top depth $(0-15 \mathrm{~cm})$ of the soil compared to the middle and lower depth. Bulk density of the soil was increases with increase in depths, this may be because of Bulk density was dependent on calcareous and saline nature of soils. Water holding capacity of the soil was decreases with increase in depths, it may be because of presence of low amount of organic matter in lower depth compared to the top soil. Specific gravity decreases with the increase in depth because specific gravity does not express the actual situation of a water saturated soil, where the pore water is saline and this dissolved salt will start precipitating during the preparation of the soil sample. Subsequently, the weight and volume of the precipitated soil will be added to that of the original soil solids. Texture of soil is varies from sandy to sandy loam soil because from the fraction of each soil separates the sand separates are found relatively higher in comparison to other soil separates.

\section{References}

Adamu, G. k., and Aliyu, A. K. 2012.Determination of the influence of texture and organic matter on soil water holding capacity in and around tomas irrigation scheme, Dambatta local Government Kano state.Research Journal of Environmental and Earth Sciences 4(12): 1038-1044.

Anonymous.1971.Munsell soil colour chart, Munsell color companyinc. $2241 \mathrm{~N}$, Calvert Street, Baltimore, marytanel21212, USA

Bouyoucos, G. J. (1927). The hydrometer as a new method for the soil texture.

Brady, N.C. and Weil, R.R. 1996. The nature and properties of soils (11th Ed.). Prentice Hall, New York.

Buoyoucos, G.J. 1952.A recalibration of the hydrometer method for making mechanical analysis of soil, 43, 434.

Chaudhari, P. R., Ahire, D. V., Ahire, V. D., Chkravarty, M. and Maity, S. (2013) soil bulk density as related to soil Texture, organic matter content and available total nutrients of coimbatore soil. International Journal of Scientific and Research Publications, 3:1-8.

Das, D. K. (2004). Introductory Soil Science 2nd Edition. New Delhi: Kalyani Publishers.

http://www.rajasthangk.co.in/2014/08/soilresource-of-rajasthan.html

Jaiswal P.C. 2006.Soil, Water and plant Analysis, Manual Practical.

Muthuaval, P.C., Udayasooriyan R., Natesan.P. P. and Ramaswami. 1998. Introduction to soil Analysis, 
Tamilnadu Agriculture University, Coimbatore-641002

Oyedele, D. J, Awotoye. O. O and Popoola. S. E. (2009) Soil physical and chemical properties under continuous maize cultivation as influenced by hedgerow trees species on an alfisol in South Western Nigeria. African Journal of Agricultural Research, Vol. 4 (7), pp. 736-739

Patel,K.P.(2015) Analysis of soil quality using physico-chemical parameters of shehra taluka District :Panchmahals (Gujarat).Indian journal of applied sciences, Volume - 5, Issue- 9,466-468

Shivakumar.D and Srikataswamy. S., (2012) study of physico-chemical characteristics of industrial zone soil - A case study of Mysore city, Karnataka, India. International Journal of
Environmental Sciences, Volume 3, No 1

Singh, R.K, and Singh, P.K., (2005), Fertility management dynamics of soil: Exploration of farmers' hidden wisdom, Asian agri-history, 9(4), pp 291-303.

Sujatha,K. N, Kavya. G,Manasa. P and Divya.K. (2016) Assessment of soil properties to improve water holding capacity in soils of Telangana region. International Research Journal of Engineering and Technology, Volume: 03 Issue: 03.

Viji, R., and Prasanna, P. R. (2012) Assessment of water holding capacity of major soil series of Lalgudi, Trichy, India. Journal of Environmental Research and Development, 7(1A) 393398.

\section{How to cite this article:}

Manpreet Kaur, Narendra Swaroop, Tarence Thomas, Arun A. David. 2017. Estimation of Physical Properties of soil of Sri Ganganagar District-Rajasthan, India. Int.J.Curr.Microbiol.App.Sci. 6(6): 307-312. doi: https://doi.org/10.20546/ijcmas.2017.606.037 